\author{
Magdalena Żyła
}

\title{
Maryjność motywem życia i konwersji Adrienne von Speyr
}

Adrienne von Speyr to świecka lekarka i mistyczka, konwertytka z kalwinizmu, żyjąca w Szwajcarii w latach 1902-1967. Recepcja jej dzieła w Polsce nadal jest fragmentaryczna ${ }^{1}$, ono zaś jest unikalne z kilku względów. Po pierwsze, choć von Speyr nie miała przygotowania teologicznego, skomentowała większość ksiąg Pisma Świętego, wnikając w nie z zadziwiającą teologa głębią. Po drugie, przez ponad dwadzieścia lat przeżywała w sposób mistyczny Triduum Paschalne, a jej doświadczenie Wielkiej Soboty rzuca nowe światło na cierpienie Chrystusa, które nie skończyło się na Krzyżu, ale trwało aż do Zmartwychwstania. Po trzecie, założona przez nią Wspólnota Świętego Jana, instytut życia konsekrowanego, wciąż przynosi owoce i rodzi powołania kontemplacyjne. To tylko nieliczne spośród argumentów na rzecz wyjątkowości postaci i dzieła.

1 Z 74 tytułów (niektóre z publikacji są kilkutomowe) wymienionych przez H.U. von Balthasara w książce Pierwsze spojrzenie na Adrienne von Speyr na język polski przetłumaczono dotąd zaledwie 9 pomniejszych. Kluczowe dla zrozumienia dzieła mistyczki teksty, w tym czterotomowy komentarz do Ewangelii św. Jana, nie są jeszcze dostępne polskiemu czytelnikowi. Zob. H.U. von Balthasar, Erster Blick auf Adrienne von Speyr, Einsiedeln 1968. W swoim tekście korzystam z wersji anglojęzycznej: H.U. von Balthasar, First Glance at Adrienne von Speyr, tłum. A. Lawry, S. Englund OCD, San Francisco 1986, s. 102-110. 
W przeświadczeniu Hansa Ursa von Balthasara, towarzyszącego jej przez dwadzieścia siedem lat swoją posługą kapłańską i teologiczną, misja Adrienne stanowi rzeczywiste kościelne posłannictwo o wyjątkowym znaczeniu i zasięgu ${ }^{2}$. To on poprosił swoją podopieczną o spisanie autobiografii, czemu sama była niechętna, jednak posłusznie to uczyniła. Zostawiła zatem obszerną dokumentację swego życia pełnego nadprzyrodzonych darów i heroicznie przeżywanego współcierpienia z Chrystusem i Jego Matką ${ }^{3}$. Dla przybliżenia istoty katolickości jej duszy i motywów konwersji na katolicyzm wydaje się niezbędne przynajmniej syntetyczne nakreślenie etapów życia Szwajcarki.

\section{1. Życie kierowane przez anioła}

Urodzona 20 września 1902 roku w La-Chaux-de-Fonds, w Górach Jurajskich, w Szwajcarii Adrienne von Speyr była drugim

2 Współbrzmi to z opinią i poparciem, jakiego udzielił Ojciec Święty Jan Paweł II, angażując się osobiście, inspirując i towarzysząc konferencji watykańskiej poświęconej kościelnej misji Adrienne von Speyr. Zob. Adrienne von Speyr und ihre kirchliche Sendung. Akten des römischen Symposiums 27.-29. Sept. 1985, red. H.U. von Balthasar, G. Chantraine, A. Scola, Einsiedeln 1986. Wszystkie tłumaczenia tekstów obcojęzycznych (o ile nie zaznaczono inaczej) - M.Ż.

3 Teolog wspomina, że zadziwiająca jest dla niego „świeżość i precyzja, z jaką [...] przywołuje [ona] wydarzenia ze swej młodości, a także cudowna łatwość w wydobywaniu znaczenia tych wydarzeń i umiejscowienia ich w szerokim spektrum jej życia zarówno przeszłego, jak i obecnego" (H.U. von Balthasar, Foreword w: A. von Speyr, My Early Years, tłum. M.E. Hamilton, D.D. Martin, San Francisco 1995, s. 9). Dalsze lata życia mistyczki opisane zostały w trzech tomach dzienników zatytułowanych przez wydawcę Erde und Himmel (Ziemia i niebo). Ostatnie wersy opisujące jej odchodzenie nakreślił sam Hans Urs von Balthasar. On też jest wydawcą i krytykiem jej dzieła, zatroskanym aż do śmierci o to, by przekazać Kościołowi powierzoną mu spuściznę. Zob. A. von Speyr, Erde und Himmel I-III, Die Nachlasswerke VIII-X, Einsiedeln 1975-1976. 
z czworga dzieci zamożnej kalwińskiej rodziny. Ojciec był okulistą, jego brat kierował szpitalem psychiatrycznym niedaleko Berna. Wśród przodków ze strony matki znaleźć można wybitnych zegarmistrzów i jubilerów. Adrienne obciążona była burzliwą i pozbawioną ciepła relacją z matką, zapoczątkowaną trudnym porodem ${ }^{4}$. Ulgę w codzienności wypełnionej matczynymi naganami, często niesprawiedliwymi ${ }^{5}$, przynosiło jej ufne życie w Bogu i dla Boga kierowane przez anioła.

Anioł uczył ją modlitwy i przebywania z Bogiem oraz kierował jej postępowaniem. Wychowywaną w protestanckim środowisku dziewczynkę od najmłodszych lat ów nadprzyrodzony przewodnik zaznajamiał z sensem wyrzeczenia i ofiary, tak że podejmowała dobrowolne umartwienia w czyjejś intencji ${ }^{6}$. Gdy inne dzieci obarczały ją jakąś winą, brała ją na siebie, aż w końcu nauczyciele przestawali jej wierzyć, gdy po raz kolejny przyznawała się do czegoś, czego nie zrobiła. Anioł nauczył ją także przebaczania doznanych niesprawiedliwości. Już w szkole podstawowej zaczęła pomagać potrzebującym - razem z koleżankami założyły związek na rzecz ubogich. Takiego postępowania nauczyła się od swej ukochanej babci, z którą często spędzała całe dnie, szyjąc ubrania dla najuboższych?

Mała Adrienne była bardzo zdolną uczennicą, w szkole nie sprawiała żadnych trudności. Tylko lekcje religii ją rozczarowały. Czuła, że taki protestantyzm, jaki jej przedstawiano, ma jej do zaoferowania jedynie pustkę. Podejmowała dyskusje z kolejnymi

4 Dopiero pod koniec swojego życia, kiedy Adrienne była szanowaną w mieście lekarką i żoną kolejno dwóch profesorów, matka zaakceptowała córkę. Możliwość tę zawdzięczała Adrienne, która wiernie wytrwała w miłości do swej rodzicielki.

5 Zob. A. von Speyr, My Early Years, s. 35-37.

6 Pewnego razu małemu diabetykowi, pacjentowi swojego ojca, zaproponowała, że nie będzie jadła czekolady, by i jemu było łatwiej z niej zrezygnować. Niestety, malec nie zdołał się na to zdobyć i wkrótce zmarł, por. tamże, s. 30 .

7 Zob. tamże, s. 19-23. 
pastorami i zawsze czuła się zawiedziona. Twierdziła uparcie, że „Bóg jest inny, On taki nie jest”" W opowieściach przekazywanych jej w szkółce niedzielnej brakowało jej Maryi, dzieci tam przedstawione były jakby sierotami bez matek. Wiedziała, że Bóg podarował ludziom Matkę, zaś Jej brak w rodzimym wyznaniu odczuwała niezwykle boleśnie. Pewnego razu usłyszała od jednej z osób, że właściwie powinna pójść do klasztoru, jednak nie zdołała dowiedzieć się w swoim otoczeniu, czym właściwie miałby on być ${ }^{9}$. Nierzadko też słyszała różne złośliwe komentarze na temat katolików.

Von Speyr od dzieciństwa była wątłego zdrowia, często chorowała, cierpiała na bóle pleców, które przykuwały ją do łóżka na długie dni. Zapadała na zdrowiu zawsze przed Wielkanocą, a anioł mówił jej, że to ze względu na Wielki Piątek ${ }^{10}$. Cierpienia były zapowiedzią łask mistycznych, które miały zostać wylane dopiero w przyszłości. Choć sama była słaba, potrafiła uspokajać pacjentów szpitala psychiatrycznego prowadzonego przez stryja. Jako dziecko nie czuła lęku przed osobami chorymi psychicznie, na modlitwie ofiarowywała Bogu za nich samą siebie ${ }^{11}$.

W 1918 roku zapadła na obustronną gruźlicę płuc, co zapoczątkowało okres walki o życie. Lekarze nie dawali jej żadnych szans, miała przeżyć najwyżej rok. Gdy znalazła się w szpitalu, matka zdawała się o niej całkowicie zapomnieć. Jednak jej dusza i umysł zachowały żywotność: uczyła się rosyjskiego, wygłaszała prelekcje o Dostojewskim, posłuszeństwie i wolności, prawdzie i jej stopniach, prawie do myślenia. Zorganizowała nawet loterię

8 H.U. von Balthasar, First Glance..., s. 20-21.

9 A. von Speyr, Aus meinem Leben. Fragment einer Selbstbiographie, Einsiedeln 1968, s. 125.

10 H.U. von Balthasar, First Glance..., s. 21. Zob. także: A von Speyr, Die Nachlasswerke, Band VII: Geheimnis der Jugend, Einsiedels 1966, s. 21-22.

11 J.S. Neuman, Mężczyzna i kobieta w Bożym Królestwie. Wprowadzenie do życia i dziet Adrienne von Speyr i Hansa Ursa von Balthasara, tłum. J. Iwaszkiewicz, Kielce 2005, s. 17. 
na rzecz rosyjskich uchodźców, ofiar rewolucji ${ }^{12}$. Koleżanka, z którą znalazła się wówczas w klinice, mawiała do niej: „Zachęcasz mnie do zostania katoliczką", czyli do czegoś, o czym jeszcze wtedy Adrienne w ogóle nie myślała ${ }^{13}$. Inna osoba miała powiedzieć: „Ty zostałaś stworzona do posłuszeństwa”" ${ }^{\text {. Jeszcze }}$ wiele lat trzeba było czekać, aby w pełni zrozumieć te słowa.

\section{Pierwsze spotkanie z Maryją}

Wtedy też, podczas rekonwalescencji po przebytej gruźlicy, po raz pierwszy von Speyr znalazła się w katolickiej kaplicy. Paląca się przy tabernakulum wieczna lampka symbolizowała obecność Pana i wówczas Adrienne zrozumiała z niezachwianą pewnością: „Tutaj, w tym kościele, jestem u siebie, tak jak inni ludzie są u siebie we własnych domach"15. Piętnastoletnią Adrienne nawiedziła Maryja, choć - jak już wspomniano - Jej bliskość nie była czymś, co dziewczyna mogła odkrywać w rodzimym wyznaniu. W swojej autobiografii opisała to następująco:

bardzo wczesnego ranka, kiedy było jeszcze prawie ciemno, obudziło mnie złote światło, które wypełniało całą ścianę nad moim łóżkiem. Zobaczyłam coś jakby obraz Najświętszej Maryi Panny, otoczonej kilkoma innymi osobami (które znajdowały się jakby w tle, podczas gdy Ona była na pierwszym planie) oraz aniołami. Niektóre były tak duże jak Ona, a inne małe niczym dzieci. To było jak obraz, ale Najświętsza Dziewica była żywa, w niebie, a aniołowie zmieniali pozycje. Sądzę, że to trwało bardzo długi czas. Patrzyłam, modląc się bez słów, cała w zachwycie. Nie widziałam nigdy niczego równie pięknego. Początkowo całe to

12 Zob. H.U. von Balthasar, First Glance..., s. 24-25.

13 Mowa o Louisie Jaques, która później została konwertytką, a następnie klaryską i zmarła w Jerozolimie w opinii świętości. Zob. tamże, s. 25.

${ }_{14}$ Mowa o paryżance Pauline Lacroix. Zob. tamże.

15 Tamże. 
światło było jak żywe, pulsujące złoto, które z czasem zaczęło blaknąć, a gdy zbladło całkiem, twarz i ręce Maryi stały się bardziej widoczne i żywe. W ogóle się nie bałam, ale przepełniała mnie nowa radość, jednocześnie intensywna i bardzo słodka. Nie miałam w ogóle wrażenia, że biorę udział w czymś nierealnym. Nie pomyślałam też, że mój umysł mógł paść ofiarą jakiejś pomyłki ${ }^{16}$.

Von Speyr wspomina, że opowiedziała o tym zdarzeniu swej kuzynce Madeleine, która rzekła tylko, że również chciałaby zobaczyć Maryję. Przez długie lata nie znajdowała nikogo, z kim można by o tym pomówić; pastorzy nie wydawali jej się odpowiednimi osobami. Nie sądziła jeszcze wtedy, że kiedykolwiek mogłaby zostać katoliczką, ale wiedziała już, że wszyscy ludzie powinni kochać Maryję. Dopiero w wieku trzydziestu ośmiu lat, przygotowując się do chrztu w Kościele katolickim, opowiedziała o tym zdarzeniu Hansowi Ursowi von Balthasarowi. Od tamtej pory cała jej misja miała, jego zdaniem, „głęboko maryjny charakter"17. Samo zdarzenie zostawiło na jej ciele ślad - po widzeniu Maryi pod lewą piersią otworzyła się rana, która nie uległa całkowitemu zabliźnieniu aż do śmierci, przez co Szwajcarka czuła się cieleśnie przynależna Bogu.

Dwa główne motywy prowadziły ją, zdaniem von Balthasara, przez lata młodości. Pierwszym z nich była „niezachwiana determinacja zostania lekarką”, drugim, równie silne pragnienie „należenia do samego Boga, [...] poświęcenia swojej całej egzystencji do Jego dyspozycji bez żadnych zastrzeżeń"18. Od protestantyzmu oddzielało ją również to, że chciała oddać się Bogu w sposób niepodzielny. Nie dopuszczała podziałów na „moje” i „Twoje”. W protestantyzmie te dwie sfery - „grzesznika” i „błogosławionego" - są oddzielane. Dla von Speyr, która miała duszę gotową

16 A. von Speyr, My Early Years, s. 166-167.

17 H.U. von Balthasar, First Glance..., s. 24.

18 Tenże, Foreword w: A. von Speyr, My Early Years, s. 10. 
do dawania bez zważania na koszty, bez rozmyślania o sobie, było to nie do przyjęcia ${ }^{19}$. Pragnęła oddania podobnego do tego, jakie uczyniła z siebie Maryja.

\section{Studia medyczne i zamążpójście}

Wybór medycyny wymagał ze strony von Speyr heroizmu, ponieważ nie posiadała wsparcia z żadnej strony. Rodzina odmówiła finansowania studiów. Zawód lekarza wydawał jej się zbyt wymagający dla kobiety. Matka, która liczyła, że córka szybko wyjdzie za mąż i zajmie stanowisko w banku, na wieść o studiach medycznych przez wiele tygodni nie odzywała się do niej i zabroniła tego pozostałym dzieciom. W trakcie nauki, aby się utrzymać, Adrienne udzielała do dwudziestu godzin korepetycji tygodniowo. Modliła się za zmarłych, których ciała miała preparować. Nocami krążyła po szpitalnych salach, by nieść pociechę chorym, nierzadko przygotowując ich do zbliżającej się śmierci.

Studia medyczne ukończyła z powodzeniem ${ }^{20}$. Aż do późnych lat pięćdziesiątych XX wieku prowadziła własną praktykę medyczną jako jedna z pierwszych kobiet w Szwajcarii. Przyjmowała do kilkudziesięciu pacjentów dziennie, ubogich leczyła za darmo. Obroniła kilkaset dzieci przed aborcją, zawsze niosła pociechę duchową, a często także wsparcie materialne, zbierając dary, które następnie rozdzielała pomiędzy najbardziej potrzebujących pacjentów.

19 Zob. tamże, s. 13.

20 Rozprawa wieńcząca studia dotyczyła porodu późnych pierworódek w klinice położniczej w Bazylei. A. Dürr-von Speyr, Die Geburt der alten Erstgebärenden an der Basler geburtshilflichen Klinik 1917-1928, Inaugural-Dissertation zur Erlangung der Doktorwürde der Hohen medizinischen Fakultät der Universität Basel, Basel 1931. 
W pewnym momencie aktualne stało się dla niej pytanie o zamążpójście. Choć czuła, że pragnie należeć tylko do Boga, nie wiedziała, jak ma to wypełnić. Zostanie protestancką diakonisą nie wchodziło w grę, gdyż nie składają one ślubu czystości, co dla von Speyr było nie do przyjęcia. Nie wyobrażała sobie też wtedy życia w klasztorze. W końcu dzięki przyjaciołom poznała bliżej, a potem poślubiła profesora Emila Dürra, kierownika Katedry Historii Uniwersytetu Bazylejskiego ${ }^{21}$. Zrobiła to, jak sama wyznała, ze względu na współczucie dla niego i jego dwóch małych synów - chciała zaopiekować się owdowiałym niedawno mężczyzną. Miała przeczucie, że jeszcze mniej przychyli się do woli Bożej, nie wychodząc za niego za mąż. Nauczyła się kochać swego męża, wiedli szczęśliwy żywot jako rodzina, choć Adrienne $\mathrm{w}$ tym czasie trzykrotnie poroniła, za każdym razem z powodu przemęczenia ${ }^{22}$. Tragiczna śmierć małżonka w 1943 roku pogrążyła ją w smutku graniczącym z rozpaczą. Po jego odejściu przez wiele lat nie mogła wypowiedzieć w modlitwie Ojcze nasz słów „bądź wola Twoja”.

\section{Konwersja}

Jesienią 1940 roku po raz pierwszy spotkała Hansa Ursa von Balthasara, nowo przybyłego do Bazylei duszpasterza akademickiego. To on niejako odblokował w niej możliwość ponownego wypowiadania słów Modlitwy Pańskiej. Z jego katechizacji przyj-

${ }^{21}$ Jej pierwszy mąż Emil Dürr zmarł tragicznie wskutek wypadku tramwajowego po kilku latach małżeństwa w 1943 roku. Wkrótce ponownie wyszła za mąż, kierując się m.in. dobrem dzieci swojego pierwszego męża, za które teraz była odpowiedzialna. Poślubiła Wernera Kaegiego, asystenta, a potem następcę Dürra w Katedrze Historii Uniwersytetu Bazylejskiego. Przeżył on swoją żonę. Oboje spoczywają na cmentarzu Friedhof am Hörnli w Bazylei.

22 A. von Speyr, Erde und Himmel, nr 1650, cyt. za: J.S. Neuman, Mężczyzna i kobieta..., s. 24. 
mowała dosłownie wszystko. Teolog opisuje to w ten sposób: „To było tak, jakbym wtedy bezwiednie nacisnął włącznik, który za jednym zamachem zapalił wszystkie światła w sali"23. Szwajcarka wyjawiła mu swe pragnienie przejścia na katolicyzm, co nastąpiło w niedługim czasie. Została ochrzczona warunkowo w uroczystość Wszystkich Świętych jeszcze tego samego roku ${ }^{24}$. Oczywiście wiązało się to $z$ wielkim skandalem w protestanckim mieście, a także pogłębieniem niechęci ze strony matki. Jednak tuż po konwersji Bóg zaczął na von Speyr wylewać zdroje łask mistycznych.

Dary duchowe zostały zapowiedziane przez anioła, kiedy pewnego dnia na początku lat czterdziestych XX wieku von Speyr wracała do domu po codziennej pracy w swoim gabinecie lekarskim. Nagle przed jej samochodem rozbłysło światło tak jasne, że jeden ze świadków relacjonujących to zdarzenie uznał je za pożar. W tym samym czasie usłyszała słowa: „Od tej pory będziesz żyła w niebie i na ziemi" (Tu vivras au ciel et sur la terre) ${ }^{25}$. Słowa te w ciągu najbliższego ćwierćwiecza miały potwierdzić się na wiele różnych sposobów.

Chronologicznie pierwszym, a także najważniejszym interpretatorem dzieła mistyczki i świadkiem jej życia, jak również redaktorem i wydawcą jej tekstów jest Hans Urs von Balthasar. Ten dysponujący wybitną erudycją teolog przyznawał pierwszeństwo dziełu von Speyr przed swoim własnym, a wydanie jej pism w formie szeroko dostępnej czytelnikom uważał za swą misję. W książce Erster Blick auf Adrienne von Speyr (Pierwsze spojrzenie na Adrienne von Speyr ${ }^{26}$ wydanej w rok po jej śmierci

${ }^{23}$ H.U. von Balthasar, First Glance..., s. 31.

${ }^{24}$ Przed II Soborem Watykańskim protestanci byli chrzczeni według różnych formuł ustalanych przez pastorów, w związku z czym istniała obawa, czy chrzest był ważny, dlatego też przy konwersji go powtarzano.

25 Tamże, Our Task. A Report and a Plan, tłum. J. Saward, San Francisco 1994, s. 183.

26 Zob. przypis 1. 
pisał: „Dziś, już po jej odejściu, jej dzieło jawi mi się jako znacznie ważniejsze niż moje własne, a publikacja jej pism ma pierwszeństwo przed moimi”"27. Teolog deklarował także: „Generalnie rzecz biorąc, teologicznie otrzymałem od niej wiele więcej niż ona ode mnie, choć oczywiście dokładne proporcje nigdy nie zostaną wyznaczone"28.

We wspomnianej książce teolog wymienia kilka charakterystycznych cech duchowości von Speyr, które mógł zaobserwować. Jako podstawowy i najważniejszy wymiar jej życia wewnętrznego oraz całego kościelnego dzieła wskazuje właśnie maryjność. Chodzi o maryjność rozumianą jako fundamentalna postawa człowieka przed Bogiem, której doskonałym ucieleśnieniem i nauczycielką pozostaje Najświętsza Maryja Panna. Gdy ten przenikliwy interpretator zastanawia się, po co i jak czytać dziś Adrienne von Speyr, zauważa, że wskazuje ona na najbardziej fundamentalne, a jednocześnie pomijane problemy. Pisała: „Protestantyzm zatracił ostateczną powagę Wcielenia, stanie się Ciałem. Dlatego właśnie wszystko pozostaje tam takie teoretyczne, spekulatywne"29. Realność wcielenia objawia się, zdaniem von Speyr, przede wszystkim na trzech płaszczyznach: relacji Matki i Dziecięcia (gdzie wszystkie dogmaty maryjne wykazują zadziwiającą logikę), poprzez posłuszeństwo możliwe do urzeczywistnienia tylko w Kościele katolickim posiadającym Urząd Nauczycielski oraz w łaskach Krzyża udzielanych w Kościele przez sakramenty ${ }^{30}$. W niniejszym szkicu interesuje nas pierwsza z wymienionych płaszczyzn. Ona też wiodła Szwajcarkę ku Kościołowi katolickiemu od najmłodszych lat jej życia.

\footnotetext{
27 H.U. von Balthasar, First Glance..., s. 13.

28 Tamże.

29 Tamże, s. 247.

30 Zob. tamże.
} 


\section{W świetle przyzwolenia}

Pierwsza samodzielna książka napisana przez von Speyr po konwersji do Kościoła katolickiego poświęcona była Maryi ${ }^{31}$. Mowa o Stużebnicy Pańskiej ${ }^{32}$, w której wstępnym rozdziale zatytułowanym Światło przyzwolenia czytamy następujące słowa:

Podobnie jak powrósło łączy pojedyncze źdźbła, tworząc z nich jeden kształtny snop, tak zgoda wyrażona przez Maryję spina Jej życie, nadając mu sens i kształt oraz wyznaczając przeszły i przyszły jego bieg i rozwój. To „związanie” określa odtąd każdą chwilę Jej istnienia, opromienia każdą zmianę w Jej życiu, nadaje szczególny sens każdej nowej sytuacji, a Ją samą we wszystkich okolicznościach obdarza łaską zrozumienia ${ }^{33}$.

Dla von Balthasara fiat Maryi jest „najbardziej pokorną rzeczą, jaką mogła ona powiedzieć czy wykonać" ${ }^{34}$, a przez to najdoskonalszą. Stanowi ono początek nowego rodzaju relacji stworzenia ze swoim Stwórcą. Przyzwolenie Maryi wyrażone było w sposób unikalny. Posługując się słowami Stużebnicy Pańskiej, powiemy, że wobec Boga „zapomina [Ona] o ostrożności”, „nie zawiera z Bogiem układu”, „nie ubezpiecza się”, „nie wyraża żadnego życzenia, upodobań, pragnień, które Bóg miałby uwzględnić" - słowem: oddaje siebie bez zastrzeżeń. Teolog pi-

${ }^{31}$ Warto wspomnieć o nieprzetłumaczonej na język polski książce $\mathrm{Ma}$ ryja w Odkupieniu, o której napisano: „Czytając książkę, można tylko za jej wydawcą [H.U. von Balthasarem - M.Ż.] stwierdzić, że może ona być pomocą nie tylko do ożywienia tradycyjnej mariologii, ale do wskazania jej nowych dróg” (S. Moysa SJ, „Collectanea Theologica” 51/1 (1981), s. 210; zob. A. von Speyr, Maria in der Erlösung, Einsiedeln 1979).

32 A. von Speyr, Die Magd des Herrn. Ein Marienbuch, Einsedeln 1948.

33 Taż, Służebnica Pańska, tłum. J. Koźbiał, Warszawa 2017, s. 7.

${ }^{34}$ H.U. von Balthasar, First Glance..., s. 51. 
sze: „oddaje swą skończoność do dyspozycji Nieskończonego”35. Czyni tym samym najlepszy użytek ze swojej wolności. „Patrząc od strony Boga - to największa łaska; ale patrząc od strony człowieka, to także największe osiągnięcie możliwe dzięki łasce: bezwarunkowe, definitywne samooddanie. Jest to jednocześnie wiara, nadzieja i miłość. [...] Jest to synteza miłości i posłuszeństwa - Jana i Ignacego"36 - podsumuje von Balthasar, interpretując teologicznie mistykę von Speyr. Jest oczywiste, że szczyt takiej syntezy realizuje Syn Boży w relacji z Ojcem, a człowiek - według św. Ignacego z Loyoli - na swoją miarę wyraża ją w relacji z Synem Bożym, który pierwszy Go umiłował i samego siebie wydał za niego (Ef 5,2; 1 J 4,19), jednak to właśnie Maryja zrealizowała ją najdoskonalej ze wszystkich stworzeń.

Von Balthasar, komentując Służebnicę Pańską, zauważa, że Maryja wyraża miłość poprzez gotowość do bycia „niczym” przed Bogiem, przez całkowitą przezroczystość, usunięcie siebie w cień. Żadne światła nie padają na Nią, wszystkie na Boga; nie są podkreślane słowa Jej zgody, ale inicjatywa i słowo Boga ${ }^{37}$. „Czyste odejście od siebie. Czysta przestrzeń dla wcielenia Słowa, w tym stanie pustki posłuszeństwo, ubóstwo i dziewictwo stały się jednym" ${ }^{38}$. Von Speyr pisze: „Całkowite przyzwolenie Dziewicy było duchowym łonem Dziecięcia. Dopiero potem łonem stało się również ciało Matki"39. Stworzenie wyrażające w ten sposób gotowość służenia Bogu umożliwia Mu kształtowanie się na wzór Jego nieskończoności. „Maryja może być ukształtowana na Matkę Boleściwą, Niewiastę z Apokalipsy, Królową Nieba i Ziemi. Najważniejsze jest to, że Kościół może być kształtowany

35 Tamże.

36 Tamże.

37 Zob. tamże, s. 52.

38 Tamże.

39 A. von Speyr, Stużebnica Pańska, s. 84. 
z Niej. Kościół idealny, taki, jaki być powinien"40. Począwszy od Maryi, dotyczy to każdego wierzącego.

Adrienne von Speyr rozumie, że odrzucenie Maryi jest poważnym zubożeniem wiary. „Ponieważ przemierzyła wraz z Synem wszystkie Jego drogi, wie, jakie ścieżki do Niego prowadzą"41. To Ona rodzi po wszystkie czasy każdego chrześcijanina, tak jak urodziła swego Syna. Nie pragnie niczego innego, jak tylko przyprowadzać do Jezusa Jego braci, szczególnie troszcząc się o powołanych do Jego ścisłego naśladowania na drodze życia radami ewangelicznymi. To ich szczególnie troskliwie wprowadza w sens powołania. W Służebnicy Pańskiej czytamy:

Ci, którzy wierzą w Chrystusa, lecz odrzucają Matkę, w gruncie rzeczy sprawili, że ich wiara nie przynosi owoców. Nie wiedzą, jak bardzo Jezus Chrystus włącza wierzącego w swoje dzieło, nakłada na niego obowiązki i współodpowiedzialność. Nie wiedzą, że uczynił On swoją Matkę warunkiem zbawienia, a wraz z Nią każdego, kto czyni wolę Ojca. Dlatego dla tych chrześcijan poznanie Matki i owocna wiara to jedno i to samo ${ }^{42}$.

Bez rozumienia współudziału Maryi w misji Jej Syna niezrozumiały staje się współudział każdego wierzącego w dziele zbawienia. Wiara staje się sprawą prywatną, a wymiar wstawienniczy przestaje mieć realne znaczenie.

\section{Bez Matki zatraca się realizm wcielenia}

Dla von Speyr Maryja oraz relacja, jaką nawiązała ona jako Matka ze swoim boskim Synem, stanowi gwarancję tego, że prawda o Emmanuelu - Bogu z nami nie stanie się abstrakcyjną ideą, ale

\footnotetext{
${ }^{40}$ H.U. von Balthasar, First Glance..., s. 52.

${ }^{41}$ A. von Speyr, Stużebnica Pańska, s. 207.

42 Tamże, s. 211-212.
} 
prawdą cieleśnie obecną pośród wiernych. Narodziny z kobiety i niemowlęctwo Syna Bożego, prawa powolnego ludzkiego wzrostu, które On przyjął, ukazują, że Słowo stało się Ciałem.

Przez przykład miłującej obecności Matki Dziecię poznaje, czym jest ludzka miłość. Matka ukazuje Mu, w jaki sposób człowiek przestaje ze swymi bliźnimi, własnym przykładem uczy Je, czym jest miłość bliźniego na co dzien. Później Syn ustali prawo: miłujcie się nawzajem; owej miłości już w dzieciństwie nauczył się w obcowaniu z Matką. Z drugiej strony Matka obdarza Go tą miłością w Duchu, którą od Niego otrzymała. Wszystko, czegokolwiek Mu udziela, już z góry należy do Niego i dlatego wszystko, czego Go uczy, jest skończenie doskonałe ${ }^{43}$.

W czasie wychowywania Maryja opowiada małemu Jezusowi „o ludzie świętym, o Prawie i prorokach. Od Niej Syn dowiaduje się, co u ludzi oznacza Tradycja (Maryja i Tradycja są ze sobą nierozerwalnie związane). Ukazuje Mu również przejście od Starego do Nowego Przymierza, przejście, którym jest Ona sama: ukazuje Mu więc samą siebie"44. Tam również, w relacjach rodzinnych w Nazarecie, stworzony został konkretny stosunek między chrześcijaninem a Bogiem. $Z$ tego właśnie miejsca wszyscy chrześcijanie, a zwłaszcza święci, czerpią probierz swojej relacji z Bogiem. Tam też chrześcijanin uczy się życia na chwałę Boga. U von Speyr czytamy:

Syn jako Bóg, Matka jako Niepokalane Poczęcie i Józef jako święty mają taki sam udział w łasce niebieskiej, jak w sprawach doczesnych. Gdyby tylko chcieli, już tu na ziemi mogliby żyć jak w niebie. Ale ich misja stawia ich na ziemi, toteż korzystają ze swego niebieskiego życia z największą ostrożnością. Dają pierwszeństwo ziemi. Tego bowiem wymaga od nich misja. Dlatego ich życie w Nazarecie nie składa się z samych przyjemności

43 Tamże, s. 110-111.

44 Tamże, s. 112. 
i radości obcowania ze sobą. Żyją dla przyszłych chrześcijan, dla nas. Dom w Nazarecie nie jest domem zamkniętym, nie jest też rajem odseparowanym od świata; otwartymi drzwiami i oknami wychodzi na Kościół, abyśmy nauczyli się wpierw porządkować swoje życie przy zamkniętych drzwiach i oknach, by następnie otworzyć je na potrzeby Kościoła ${ }^{45}$.

Ponadto Maryja nie przekazuje nam nigdy prawdy niebieskiej bez pośrednictwa zmysłów. Mistyczka, która doświadczyła obcowania z Maryją, stwierdza: „W tym, co objawia nam o Synu, żyje nadal to, co widziała, słyszała i czuła, wszystkie miłe poruszenia Dziecięcia w Jej łonie i na Jej piersi, cała dotykalność ziemskiego żywota Syna"46.

\section{Maryja nauczycielką modlitwy}

Życie chrześcijanina jest prawdziwe i owocne wtedy, kiedy trwa on na modlitwie, odkrywając Boga jako tego, który ma mu nie tylko coś do powiedzenia, ale też obdarza go powołaniem. Aby to powołanie pojąć i wypełnić, trzeba zanurzyć się w modlitwie. Maryja w czasie swej egzystencji przeszła różne etapy życia modlitewnego, dlatego na tej drodze jest pewną przewodniczką. Jako pierwsza kontemplowała Ona tajemnicę wcielenia, która się w Niej dokonała. Później jednak modlitwa przybierała inne formy.

Matka wie, jak należy przyjmować tajemnice Boże. Rzeczy Boże można w ogóle zobaczyć tylko z dystansu szacunku, uwielbienia, miłującej adoracji i otulenia. [...] Mają one w sobie tyle z atmosfery niebiańskiego świata tajemnic, że dają się postrzegać tylko w ciszy, modlitwie i kontemplacji. [...] Przekazując Kościołowi

Tamże, s. 116.

46 Tamże, s. 215. 
tajemnice, które rozważała i którym zapewniła wzrost w łonie swego ducha, Maryja przekazuje mu też coś z ducha własnej kontemplacji. I dlatego chrześcijanie tylko w głębi ukrytej ciszy serca Maryi odnajdują prawdziwą drogę do wewnętrznego świata Jej Syna. A właśnie modlitwy maryjne: nowenna, litania, różaniec - wymagają spokoju, dystansu, czasu i te wartości budują. Są one ćwiczeniem się w kontemplacji Matki, która pośredniczy w osiągnięciu kontemplacji Syna ${ }^{47}$.

Kiedy Jezus opuścił dom w Nazarecie, by realizować misję powierzoną Mu przez Ojca, Maryja przestała opiekować się Nim i pracować dla Niego jak dotąd. Zmieniła się również Jej modlitwa. Choć nie była już obecna w życiu Syna tak jak wcześniej, Jej odpowiedzialność za Niego się nie zmniejszyła - „przesunęła się ona w kierunku większej współodpowiedzialności”48. Szwajcarka pisze, że odtąd Maryja towarzyszy Mu na drodze kontemplacji. Jej macierzyńska misja przekształcona została teraz w misję towarzyszenia Synowi w Jego dziełach, „w modlitwie Syn zaprasza Ją nieustannie do współdziałania"49.

Współdziałanie to realizuje się poprzez skuteczną modlitwę, przebywanie z Ojcem i Synem w Duchu Świętym, oddawanie Synowi do dyspozycji owoców swej kontemplacji, które może On dowolnie wykorzystywać bez oglądania i smakowania ich. Jest to wzór i początek życia kontemplacyjnego Kościoła, a także źródło mistyki w Kościele. Maryja przed poczęciem praktykowała kontemplację o nieco abstrakcyjnym charakterze, by dzięki poczęciu, brzemienności i narodzinom ją ukonkretnić, a taką pozostawić następnie aż do końca życia Syna. „Kiedy zaś Syn odchodzi z tej ziemi, a w wyniku wydarzenia wielkanocnego staje się Człowiekiem duchowym przebywającym w niebie, bynajmniej nie strąca Matki z powrotem w tę pierwszą, abstrakcyjną formę medytacji.

\footnotetext{
47 Tamże, s. 106.

48 Tamże, s. 126.

49 Tamże.
} 
Pozostaje w Niej, w Jej duchu i zmysłach, i to nie tylko jako wspomnienie, lecz także jako wypełniająca, wieczna obecność"50. Jest to dar, który Maryja - jak wszystko własne - przekazuje Kościołowi; to dar "nieśmiertelny po wszystkie czasy” ${ }^{51}$.

\section{Maryja współcierpiąca uczy cierpienia}

Przynosząc na ofiarowanie Dziecię do świątyni, Maryja czuje się samotna. Wcześniej stanowiła z Nim jedno, teraz misja Syna zaczyna się wyodrębniać, stając się dla Matki powoli coraz bardziej wymagająca. Daje temu wyraz starzec Symeon, który rozpoznaje Ją i Dziecię w Duchu Świętym. Rozumie on, że tam na Matkę cierpienie spada po raz pierwszy. Musi się Ona zmierzyć z tym, że oto Jej Syn należy przede wszystkim do Boga. Zwyczajność dotychczasowego życia zostaje przerwana. Choć posłuszeństwo ziemskim rodzicom zostało wypowiedziane tylko na chwilę, to Matka rozumie, że „ta rana nigdy się już nie zabliźni, lecz będzie się coraz bardziej pogłębiała" ${ }^{2}$. Rozumie także, że „wszystko, co Syn czyni w tej chwili i co zapowiada na przyszłość, wskazuje na to, że powróci On do Ojca na drodze, którą wraz z Ojcem wybrali i na której będzie się stawał coraz potężniejszy i bardziej Boski. Powróci w cierpieniu, które będą dzielić oboje - Matka i Syn. Na krzyżu On również postawi Ojcu pytanie, na które nie otrzyma odpowiedzi”"53.

Maryja uczy, że Krzyża nie można zrozumieć, można go pojąć tylko wtedy, gdy zrezygnujemy z rozumienia, oddając własną niemoc Bogu. Tę tajemnicę Matka zachowuje w sercu po powrocie do Nazaretu, a w pełni przyjmie ją, towarzysząc Synowi podczas konania. To wtedy reprezentuje Ona wiarę doskonałą.

\footnotetext{
50 Tamże, s. 205.

51 Tamże, s. 206.

52 Tamże, s. 123.

53 Tamże.
} 
Postawa Maryi pokazuje, że tylko „żywa wiara może runąć w noc niewspółmiernej wielkości Boga"54.

\title{
9. Matka u początków nowej wspólnoty
}

Przyzwolenie Maryi nie tylko zapoczątkowuje nowy rodzaj relacji stworzenia ze Stwórcą, ale także pozwala na zawiązanie stanu życia nieznanego w Starym Przymierzu. Jezus ten nowy stan w swoim Kościele buduje na Maryi i Janie, swoim umiłowanym uczniu. Na Maryi właśnie dlatego, może się odwołać do Jej pierwotnej zgody, by z tego samego źródła wyprowadzić nową płodność - płodność ślubów. Na Janie, gdyż „pod postacią krzyża chce mu dać najpiękniejsze, co posiada"55. Stan ten ma więc swoje źródło w krzyżu, a pierwowzór stanowi miłość Matki i apostoła, któremu została powierzona dziewicza cząstka Kościoła.

\begin{abstract}
Maryja - Niepokalane Poczęcie - dała nieograniczone przyzwolenie, które Pan mógł bezgranicznie formować i poszerzać. Matka nigdy nie stawiała Mu granic. Była zawsze tym, czego od Niej w danej chwili oczekiwał. Zawsze współbrzmiała z Nim harmonijnie. I dlatego teraz jest łonem Kościoła. [...] Wszystkie przymioty, jakie posiadała w czasie ziemskiego żywota Pana, otrzymuje z powrotem, spotęgowane i uduchowione, by sprostać swemu nowemu zadaniu: staje się kolebką Kościoła ${ }^{56}$.
\end{abstract}

Maryja jest wzorem Kościoła. Duch Święty ukształtował w Niej przy zwiastowaniu cielesnego Syna. Następnie Syn w Duchu Świętym kształtował w Niej - cielesnej Matce - Oblubienicę. Przy Zielonych Świątkach ten sam Duch posłany przez Syna,

\footnotetext{
54 Tamże, s. 124.

55 Tamże, s. 168.

56 Tamże, s. 177.
} 
który wrócił do Ojca, zstępuje, by „to drugie osłonięcie Maryi utworzyło Ciało Kościoła w całej jego konkretności" ${ }^{57}$. Potencjał macierzyński Maryi ukonkretnia się w pełni w wyniku tego drugiego - dla Niej drugiego - zstąpienia Ducha Świętego. Owoc tego jest tak zachwycający, jak tylko może być owoc współpracy Boga z człowiekiem, który nie jest obarczony grzechem. Oto właśnie „Maryja staje się normą, ideą, wzorem Kościoła. Tylko w Niej Kościół jest dokładnie taki, jaki powinien być - jest Oblubienicą bez zmazy i skazy. Od Niej właśnie Kościół otrzymuje zdolność współbrzmienia we wszystkim ze swym Oblubieńcem ${ }^{58}$.

Czytamy: „Maryja we wszystkich swych związkach i w każdej fazie życia pozostaje Oblubienicą. Być Oblubienicą to być wiecznie gotową do ofiarowania siebie"59. Do takiego właśnie ideału mają dorastać członkowie założonej przez Adrienne von Speyr Wspólnoty Świętego Jana (Johannesgemeinschaft).

Jej powstanie wiąże się z szeregiem mistycznych przeżyć von Speyr, a także pracą intelektualną, którą Adrienne wykonała między innymi nad analizą reguł, błędów i klęsk istniejących już zakonów i kongregacji, co miało na celu uniknięcie powtórzenia ich historii. Od 1941 roku miała świadomość tego, że pełni wobec młodych kobiet pewną misję, którą powierzyła jej Maryja. Wówczas nie wiedziała jeszcze, co to będzie. Nigdy jednak nie myślała o zakonie w klasycznym tego słowa znaczeniu. Chodziło jej raczej o wspólnotę osób zaangażowanych w świecie, wnoszących swój pełnowartościowy wkład, ale żyjących pogłębionym życiem duchowym w świetle codziennej medytacji Słowa i kontemplacji ${ }^{60}$.

Szwajcarka miała rozmaite wizje poprzedzające założenie Johannesgemeinschaft. Kilkakrotnie widziała Maryję z Dzieciątkiem na ręku, co miało symbolizować nową wspólnotę. Innym razem Matka Pana ukazała się jej brzemienna i prosiła o pomoc

57 Tamże, s. 179.

58 Tamże.

59 Tamże, s. 82-83.

60 Zob. taż, Erde und Himmel, nr 40, 107. 
przy narodzinach dziecka-wspólnoty ${ }^{61}$. Mistyczka czuła, że całe niebo nalega w tej sprawie. Jednocześnie doświadczała też wizji tego, co stanowić będzie zagrożenie - czarne ptaki zmieniające się w kobiety, które już nie chcą się modlić, symbolizowały wewnętrzne problemy; tym większą wagę przywiązywała zatem do ducha pokuty ${ }^{62}$.

Ostatecznie wspólnota została założona w uroczystość Niepokalanego Poczęcia Najświętszej Maryi Panny 8 grudnia 1944 roku w Bazylei. Początkowo posiadała tylko gałąź żeńską, potem dołączyły także męska i kapłańska (1983). Wszystkie trzy istnieją do dziś. Wspólnotę, obok współpracy przy dziele komentarzy biblijnych, uznać należy za drugi wiodący obszar kościelnej działalności von Speyr i von Balthasara. Mistyczka pisała: „Tak oto prawdziwa tajemnica płodności [...] nie spoczywa w jednym konkretnym człowieku, ale zostaje powierzona wspólnocie (Gemeinschaft), która zawsze przekracza sumę poszczególnych członków ją tworzących. Sama tajemnica wspólnoty spoczywa w rękach Boga. Każda prawdziwa wspólnota, to jest taka zawiązana pomiędzy ochrzczonymi, pochodzi od Boga, do Niego zmierza i jest tajemnicą życia w Nim..." ${ }^{63}$. Balthasar uważał, że „tylko jeśli będą powstawały wspólnoty takie jak ta, będzie można w poważny sposób pomóc dzisiejszemu Kościołowi”"64.

Johannesgemeinschaft ma charakter Janowy, czyli - posługując się uproszczeniem koniecznym ze względu na rozmiary niniejszego szkicu - kontemplacyjny. Wspólnota jest głęboko maryjna również dlatego, że Janowi została pod krzyżem po-

61 Tamże, nr 874.

62 Zob. tamże, nr 384; Adrienne von Speyr und ihre kirchliche Sendung..., s. 51.

63 A. von Speyr, Johannes IV. Geburt der Kirche, Einsiedeln 1949, kom. do $\mathrm{J} 17,3$.

${ }^{64}$ H.U. von Balthasar, Duch i ogień. Rozmowa Michaela Albusa z Hansem Ursem von Balthasarem, w: tenże, O moim dziele, tłum. M. Urban, Kraków 2004, s. 85-86. 
wierzona Matka. Swoje źródła ma więc ona w krzyżu - z niego wychodzi i do niego zmierza. Jej członkom zadane jest posłuszeństwo krzyżowi i jego ubóstwo ${ }^{65}$. Wymiar maryjny urzeczywistniany jest szczególnie w gałęzi żeńskiej. Gotowość pełnienia woli Boga na wzór Służebnicy Pańskiej ma cechować członkinie wspólnoty. Jeśli jednak ma to być wspólnota prawdziwie katolicka, nie może pozostawać w złudnej samowystarczalności, ale musi otwierać się, zdaniem założycieli, na owocną, uporządkowaną relację z kapłańską gałęzią męską ${ }^{66}$.

\section{Podsumowanie}

Tak oto podjęty w niniejszym szkicu maryjny wymiar konwersji szwajcarskiej kalwinki stanowi w istocie nić przenikającą wszystkie etapy jej życia, myślenia i posłannictwa. Owocuje on poświadczoną w imieniu Kościoła i dla Kościoła przez von Balthasara głębią ożywczych teologicznych treści. W samym kościelnym życiu zaś wszystko to owocuje w płodnej wspólnocie pomagającej Kościołowi w dziele odnowy ku realizacji jego misji. Bez wątpienia adekwatne ujęcie wymiaru maryjności stanowi warunek i podstawę właściwego odczytywania innych aspektów mistycznego doświadczenia Szwajcarki, które, zdaniem przywoływanego teologa z Bazylei, zawierają „duchową strawę dla całych pokoleń" ${ }^{67}$. W szczególności chodzić może tu o przybliżenie Kościołowi zasadniczego wkładu von Speyr, jakim, zdaniem von Balthasara, jest zgłębienie misterium zstąpienia Chrystusa do Otchłani. Również tutaj kluczowe będzie ujmowanie obu misteriów - Matki i Syna, maryjności i pasyjności - w ich harmonii i przenikaniu.

65 Zob. tenże, Our Task, s. 125.

${ }_{66}$ Zob. tamże, s. 127.

67 Tenże, Duch i ogień. Rozmowa Michaela Albusa z Hansem Ursem von Balthasarem, w: tenże, O moim dziele, s. 85-86. 


\section{The Marian principle as motive of life and conversion Adrienne von Speyr's}

Adrienne von Speyr (1902-1967) was a laywoman, wife, medical doctor, spiritual writer, and Catholic mystic, founder of secular institute Community of St. John. Originally a Reformed Protestant, she converted to Catholicism on the Feast of All Saints, 1940. She stayed under the spiritual direction of the great Jesuit theologian, Hans Urs von Balthasar. After her conversion, von Speyr began to have many mystical experiences. In my paper I show that her conversion and whole life has deep Marian character and should be considered as one of the most interesting mission in Catholic Church in twentieth-century. 